\title{
Strengthening Social Studies Literacy in the Social Distancing Policy Paradigm in the Covid-19 Pandemic Era (Study of Basic Understanding of Junior High School Students in the South Region of Garut Regency)
}

\author{
Tetep $^{1 *}$ Nita Laela ${ }^{1}$ Triani Widyanti ${ }^{1}$ Hilmi Nurfaizan AM $^{1}$
}

\author{
${ }^{1}$ Indonesian Institute of Education, Indonesia \\ *Corresponding author. Email: tetep@institutpendidikan.ac.id*
}

\begin{abstract}
Covid 19 Pandemic phenomenon has given birth to a new social and cultural order in the lives of people in the world including Indonesia. The existence of the Social Distancing paradigm gave birth to a new understanding for the community including junior high school students who are closely related to social studies subjects. The policy of implementing Social Distancing has been responded to by various elements of the community. This then encourages the writer to examine the understanding of junior high school students who have been learning about social studies education, how their understanding is related to the application of social distancing, how they react to it and its implementation in their learning activities and how the relationship between the application of social distancing is with strengthening social literacy. This study uses a quantitative approach in which the sample is junior high school students in the southern area of Garut regency as many as 97 students drawn from grades eight and nine. The results showed that students' understanding varied with the most understanding of social distancing that studied at home (56.4\%). Most attitudes and implementations state that they follow the direction of the school to study at home and follow distance learning $(62.5 \%)$. There is a positive significance $(45.7 \%)$ between the application of social distancing in schools with strengthening social literacy, especially in the discipline of maintaining social distance and social solidarity. This research has implications for the provision of knowledge and understanding of social distancing policy needs to be done on a massive scale so that it has implications for healthy behavior and social attitudes among students and the community.
\end{abstract}

Keywords : Social Studies Literacy, Social Distancing, Covid 19 Pandemic

\section{INTRODUCTION}

The world is currently experiencing an extraordinary event, where every country is battling the Corona virus which has become a pandemic. This virus is thought to have occurred on November 17, 2019 in the city of Wuhan, China, but cases were still unknown at that time and until now the search for the first patient with the Corona virus is still continuing. This virus is increasingly frightening for residents because it is linked to Severe Acute Respiratory Syndrome (SARS), which killed nearly 650 people in China and Hong Kong in 2002 and 2003.

The new type of corona virus currently attacking the world community in medical terms is known as the 2019 Novel Coronavirus (2019-nCoV) and the public then calls it COVID 19. The corona virus is a type of virus that is identified as the cause of disease in the respiratory tract. This virus suddenly became a terrible terror for the world community, especially after killing hundreds of people in just two weeks [1].
As for the symptoms of a person infected with the corona virus, according to the Central Java Health Office (Dinkes), "the corona virus that is transmitted to humans can cause inflammation of the respiratory tract. In the most critical condition, a person with the corona virus can increase his body temperature drastically more than 38 degrees Celsius. "Then the sufferer experiences headaches, dry coughs, sometimes shortness of breath. But for the most severe infections you can experience respiratory failure, "said Yulianto [2]. According to the World Health Organization (WHO) the spread of COVID 19 is already at an emergency level. This can be seen by the spread of the COVID-19 pandemic throughout the world, including The Indonesian government formed a Task Force for the Acceleration of Handling Covid19. This is a significant step in overcoming covid-19 so that the spread can be minimized immediately. There are several ways that the Task Force for the Acceleration of Handling COVID-19, including:

$$
\begin{aligned}
& \text { 1. } \quad \text { stay at home }(\mathrm{SAH}) \\
& \text { 2. }
\end{aligned}
$$


3. Work at home (WFH)

4. large-scale social restrictions (PSBB)

5. closure of an area (Lockdown)

One of the ways the government has taken to decide the spread of COVID 19 is through the Social Distancing policy. Social Distancing/social distancing is an important step that must be taken by the community including students and university students. The students responded very diverse to the application of social distancing. Understanding of social distancing is defined by students as learning activities at home, not playing with other friends, not playing with other friends, not exercising outside the home, not interacting socially, not communicating with other people, and so on.

The difference in understanding of the social distancing policies that students have depends on their understanding of the information presented by the mass and electronic media. In fact, they will link it to the knowledge they already have through learning that is obtained in school. One of the students' knowledge will be related to social studies learning in schools. Therefore, it is necessary if students' social studies literacy is further strengthened so that they can equip themselves with various knowledge, insights, skills and social intelligence, in another view how social competence flies, namely communicative abilities or the ability to communicate and build social relationships. This communication skill is related to a person's ability to socialize, participate and deliver media content well [3]-[5]. Literacy is a social event that involves certain skills, which are needed to convey and obtain information in written form [6].

Social studies as part of education, not only equips students with knowledge that burdens them, but also equips them with social knowledge that is useful and can be applied in everyday life. Literacy in social studies is an alternative form of cultivating students' social values. Strengthening Social Studies Literacy is expected to be able to equip students in the ability to read, interpret, and analyze the information and knowledge they get to give birth to a prosperous life (superior civilization) and become part of a society having a high social character [2].

Based on the above opinion, it can basically be explained that literacy is a social event equipped with skills to create and interpret meaning through text. Literacy requires a series of abilities to convey and obtain information in written form [7]. Social studies literacy can build students' intelligence in understanding and applying social sciences in real life in the community. With the Social Studies Literacy obtained through learning, it is hoped that students can be active in community activities, students do not mean that they have to know all social issues. However, what students need to do, at least is to be able or should be involved in every activity to bridge the gap between what is learned in school and the real world where the students are [8].

They should be able to practice their skills and apply their knowledge. In addition, they must prepare themselves to be smart people and act responsibly in social affairs, where they are and become part of community life and become good citizens. As one example of being a good citizen, students are able to understand and implement policies made by the government. Including the Social Distancing policy that is being promoted by the government to maintain the health and safety of its citizens so as not to contract COVID-19.

\section{THEORETICAL FRAMEWORK}

The government has enacted Health Law No.6 of 2018 , as an effort to break the chain of spreading the corona virus. "Quarantine is the limitation of activities and / or separation of a person who is exposed to an infectious disease as stipulated in the laws and regulations even though he has not shown any symptoms or is in the incubation period, and / or separates containers, Transport Equipment, or any goods suspected to be contaminated from people and / or goods that contain disease-causing or other sources of contamination to prevent possible spread to people and / or goods around them" [9].

The determination of the Social Distancing policy is part of the contents of the law. According to the Center for Disease Control (CDC), Social Distancing is the act of staying away from all forms of association, maintaining distance between people, and avoiding various meetings that involve many people. It can be interpreted that, Social Distancing is a limitation of social distance [1].

The implementation of social restrictions must be based on epidemiological considerations, the magnitude of the threat, resource support, technical operations, economic, social, cultural and security considerations; so that there may be differences in policies between the central and local governments according to regional conditions. Apart from pandemic prevention practices, in social science, the term social distance is an important concept.

There are several definitions of social distance, in essence, it is a measure of the closeness felt by individuals or groups to other individuals or groups in social networks. Here are some things related to social distancing [10]:

a. The affective dimension how much sympathy the members of a group feel for another group. This symptom is measured by Bogardus (1947) in a scale based on the subjective conception of actors in social interactions.

b. The normative dimension refers to widely accepted and consciously positioned norms about who should be considered "insiders" (us) and who "outsiders" (they). Normative social distance differs from affective, because it is understood as a non-subjective structural aspect of social relations (Park:1924).

c. Interactive dimension, focuses on the frequency and intensity of relationships between individuals or groups. This conception is similar to network theory (Garnovetter:2005), where the frequency of 
interactions between two parties is used as a measure of the "strength" of social bonds.

d. Cultural dimension drawn from the perspective of Bourdieu (1990) about the cultural capital and habits of a person who will form a separate "social class". In this context, a person's lifestyle will differentiate it from others.

The social distancing policy that has been set by the government must certainly be understood by everyone, including students. Students' understanding of this social distancing policy depends on the knowledge and insights they have. Knowledge and insights possessed by students can be built from literacy activities. The Prague Declaration in 2003 states that literacy also includes how a person communicates in society. Literacy also means practices and social relationships related to knowledge, language, and culture (UNESCO, 2003) [11]. This means that the meaning of literacy can be defined as how a person communicates with others in a community environment. Literacy is a complex process that involves prior knowledge, culture, and experience to develop new knowledge and deeper understanding [12]. Literacy is also a social event that involves certain skills, which are needed to convey and obtain information in written form [6].

Literacy activities can cover various fields of science including literacy in social sciences (IPS) [13]. Social studies literacy is not just reading, memorizing social studies material, but especially how students with social studies literacy are able to become part of society by obeying and obeying applicable rules. That the real test in social studies occurs when students are outside school, namely living in the community. If schools provide new insights to students, increase skills or awareness and high sensitivity about societal problems, then since the learning process at school, students need to be introduced to how to behave outside of school, both as children and as adults [14]. In other words, the objectives of social studies should be tested by means of students applying the concepts obtained in class to be practiced in life in society[14]. In order to be active in community activities, students do not mean that they have to know all social issues. However, what students need to do, at least is be able or should be involved in every activity to bridge the gap between what is learned in school and the real world where the students are located. They should be able to practice their skills and apply their knowledge and prepare them to become intelligent people and act responsibly in the public affairs where they are and become part of community life.

So, with this social studies literacy students are expected to be able to respond well to things that are happening such as the incident of COVID 19. The form that can be taken by students is to follow all government policies to break the chain of spread of the Coronavirus pandemic disease. One of the policies is Social Distancing, where this policy will be responded to differently from one student to another.
The Social Distancing policy is a policy made by the government, but the policy is only a guide for action and does not force it like the law. Even though the policy regulates what can be done and cannot be done, it is adequate and interpretive in nature. Because the policy is adaptive and interpretive, including the Social Distancing policy, it will cause students' understanding of the policy to be different. This difference is due to the different observations by the five senses of the students. Relating to the truth values held by these students and influencing the attitudes that will be taken by them later.

\section{METHOD}

This research was conducted from April to June 2020. Subjects / samples of the study were students (97 respondents) of SMPN in the South Garut area who owned and used cellphone facilities (HP). This study aims to determine the correlation of social distancing policies on strengthening social studies literacy. Based on the research objectives, the appropriate method for this study is the quantitative method [15]. This study uses a quantitative approach through interviews and filling out questionnaires to a sample of junior high school students. Data analysis and processing techniques were carried out with the assistance of SPSS 24 media, to test the simple linear regression correlation hypothesis [15].

\section{RESULTS AND DISCUSSION}

Based on the results of data analysis that the researcher has obtained as well as answering the problems that have been formulated as follows;

a. Students' understanding of the Social Distancing policy

Students' understanding of the social distancing policy tends to be hesitant. This can be seen in the answers of 67 respondents to the questionnaire on variable $\mathrm{X}$ (Social Distancing policy) in the value of 2338 , in the range of 2412 (doubtful) and 1608 (disagree). This means that students' opinions on the social distancing policy in the field are responded to differently. This can be understood because Social Distancing in it has dimensions of social and emotional relations. Therefore, it seems that the social distancing policy is not fully understood by respondents as a strategy to prevent the spread of Covid-19. Because, even though Covid-19 is very unsettling for the community regarding personal health and safety, the bonds of social relations are still stronger from the perspective of the community including respondents.

Talking about the theory of Social Distance Scale (social distance) made by Bogardus, this theory is actually used to measure empirically about people's willingness, whether they want to make social contact or not. The social contacts in question originate from various levels and involve all groups of society. Starting from social groups, races, and ethnicities [16].

Social distance describes the distance between various groups in society and is not a distance (location) [17]. This notion includes not only differences such as social class, race / ethnicity, gender or sexuality, but 
also the fact that members of different groups are less mingled than members of the same group. This term is often applied to cities, but its use is not limited to cities.

In literary sociology, social distance has the following approaches:

1) Affective social distance: a social distance approach that focuses on affective. According to this approach, social distance is related to distance affective, namely how sympathetic a group member is to another group. Emory Bogardus, creator of the "Bogardus social distance scale" theory of the scale based on the concept of subjectiveaffective social distance: "[i] $\mathrm{n}$ social distance studies the reaction of a person's feelings towards other people and to other groups."

2) Normative social distance: this second approach emphasizes social distance as a normative view. Normative social distancing refers to acceptance of mutual agreements and statements about norms that regard a person as an "insider" or an "outsider / stranger." These norms, in other words, determine the difference between "us" and "them." Therefore, normative social distance is different from affective social distance. Examples of this concept can be found in several works by sociologists such as Georg Simmel, Emile Durkheim and Robert Park.

3) Interactive social distance: a third approach argues that social distance focuses on the frequency and intensity of interactions between two groups, claiming that the more members of the two groups interact, the closer they will be socially. This concept is similar to the sociological approach to network theory, in that the frequency of interaction between two parties is used as a measure of the "strength" of the social bonds between them [16].

These three approaches can be viewed as possible dimensions of the concept of social distance that do not overlap with each other. Members of two different groups may interact with each other quite often, but that does not necessarily mean that they will feel "close" to one another. Normatively they will regard each other as members of the same group.

Social distancing has also been interpreted differently by an anthropologist and cross-cultural researcher named Edward T. Hall, who describes psychological distance as an animal that can feel anxious when it is far away from the herd. This phenomenon applies to infants and toddlers who walk or crawl away from their parents or caregivers and then feel anxious and then return to their safe zone a moment later. The social distancing that babies have is very simple.

Edward T. Hall also noted that the concept of social distancing can be created from technological devices such as telephones, walkie-talkies, and television. Edward T. Hall's social distancing analysis was carried out before the Internet developed, after which social distancing multiplied. Current social distance even reaches areas outside the planet Earth, such as when the earth sent humans to outer Earth on a space mission. Bogardus' term Social Distance was later adapted by the World Health Organization (WHO). WHO has adapted this term to reduce the risk of spreading the corona virus, one of which is social contact. Social Distance according to WHO is divided into several categories.

Starting from maintaining a minimum distance of 1 to 1.5 meters from other people, to stopping all forms of social activities (from school to work). Then a new question arises: why is social distancing important to do? As mentioned earlier, the spread of the corona virus can occur, one of which is because there is social contact, between one human and another. If you want to reduce the risk of spreading the corona virus, then one human being with another human being must not have social contact.

The reality in the application of social distancing policies can be seen in people's behavior, where the use of the term social distancing becomes a dilemma in its application. (1) People find it difficult to carry out social distancing because of their habits of togetherness, cooperation, solidarity, and the like as a form of social interaction.(2) For the general public, they think that social distancing is only limited to maintaining distance.

Even though, this condition is still a personal problem of respondents because there are still respondents who are not easy to do. In other words, it is very clear that there are temporary problems faced by the community including respondents related to social distancing.

b. Student Opinions about Social Studies Literacy Students' opinions about social studies literacy tend to agree. On the basis of the answers of sixty-seven respondents in the questionnaire about student opinions on Social Studies Literacy, the total score obtained is 2447 , so that the respondent's answer falls into the category of approaching doubt and agreeing because it lies between 2412 and 3216 points. This shows that respondents tend to agree with social studies literacy.

This means that respondents have the same opinion about social studies literacy, that with the social distancing policy it can strengthen social studies literacy for junior high school students in South Garut. Literacy in social studies learning is an alternative for strengthening students' abilities to read, write, appreciate, and respond to all forms of events or events in their daily lives.

With regard to this the term literacy comprehensively is as follows:

Literacy is the use of social and historical and cultural situation practices in creating and interpreting meaning through text. Literacy requires at least an unspoken sensitivity about the relationships between textual conventions and the context of their use and ideally the ability to reflect critically about those relationships. Being sensitive to goals / objectives, literacy is dynamic - not static - 
and can vary between and within communities and cultures of discourse / discourse. Literacy requires a range of cognitive abilities, knowledge of written and spoken language, knowledge of genres, and cultural knowledge [18].

From the above statement it can be seen that literacy requires complex abilities. The knowledge about genre is knowledge about the types of texts that are applied/used in the discourse community, for example, narrative texts, expositions, descriptions and others. There are seven elements that make up this definition, namely with regard to interpretation, collaboration, convention, cultural knowledge, problem solving, reflection, and language use. These seven things are the principles of literacy.

There are seven principles of literacy education, namely, (1) literacy involves interpretation. The writer/speaker and reader/listener participate in the act of interpretation, (2) literacy involves collaboration. (3) literacy involves convention. (4) literacy involves cultural knowledge. (5) literacy involves reflection and self-reflection. (6) literacy is not limited to language systems (spoken/written). (7) Literacy is the ability to identify, determine, find, evaluate, create effectively and organized, use and communicate information to solve various problems [18].

From the explanation above, it can be concluded that literacy involves interpretation, collaboration, convention, culture, self-reflection, and language systems (language users). Each individual needs to have these abilities as a condition for participating in society, and they are part of the basic human right regarding lifelong learning. Literacy activities have been synonymous with reading and writing activities. However, literacy also includes how a person communicates in society.

c. Correlation of social distancing policy with Social Studies literacy

Correlational analysis of the data shows that there is a significant positive relationship between students' perceptions of social distancing policies and social studies literacy among students in South Garut. This is evidenced by the results of the calculation of the correlation, obtained a significance value for the relationship between all independent variables and the dependent variable with a value below $0.05(<0.05)$, namely Sig. (1-tailed) $0.003<0.05$, respectively. So it can be concluded that there is indeed a significant relationship and a close correlation between all independent variables and the dependent variable.

Based on the results of the hypothesis test by determining the level of significance $=5 \%(0.05)$ and the degree of freedom for $\mathrm{dfl}=1$ and $\mathrm{df} 2=65$, it is obtained from the table F-table $=3.99$ (in the statistics book). Because F-count $=8,278>$ F-table $(0.05) / 3.99$, $\mathrm{H} 0$ is rejected and $\mathrm{H} 1$ is accepted. The conclusion is that the independent variable $(\mathrm{X})$ significantly contributes to the dependent variable (Y).

This shows that Literacy (IPS) greatly influences each student in providing an understanding of Social Distancing policies. With, Literacy (IPS) opens a window of human thought to something that is happening in society or the world. According to Alberta, literacy is the ability to read and write, increase knowledge and skills, think critically in solving problems, and the ability to communicate effectively which can develop potential and participate in community life.

Literacy is more than just reading and writing skills. But more than that, literacy is an individual's ability to use all his potential and skills in his life. With the understanding that literacy includes the ability to read words and read the world [8]. This is in line with the opinion of Grabe \& Kaplan (1992) and Graff (2006) that defines literacy as the ability to read and write (able to read and write) [19]. The ability to read and write is indispensable to build a critical and creative attitude towards various phenomena of life that can foster refinement, solidarity and as a form of effort to preserve the nation's culture. A critical and creative attitude towards various life phenomena automatically demands personal skills that focus on rational thinking skills. Rational thinking skills promote the ability to gather information and find information.

Based on the above statement, it can be concluded that government policy through the Social Distancing policy is applied to every community, including students. For junior high school students/students, the Social Distancing policy is expected to strengthen the ability in social studies literacy.

\section{CONCLUSION}

Based on the results of the research and discussion that has been described, it can be concluded that the Social Distancing policy is one of the policies implemented by the government to reduce and maintain community infection from COVID-19. This policy becomes a general guideline for the community in carrying out their daily activities. The Social Distancing policy applies to all groups, including students and university students. Students must understand what can and cannot be done in the social distancing. Therefore, every student must fully understand the Social Distancing policy. Students' understanding in responding to Social Distancing will have an impact on increasing their insight and knowledge. Literacy activities will also get better, especially in Social Studies Literacy. Social studies literacy is not only an activity to gather information through reading and writing activities, but how someone communicates with others in the community. Literacy is a stage of social behavior, namely the ability of individuals to read, interpret, and analyze the information and knowledge they get to give birth to a prosperous life (superior civilization). Students' understanding of the Social Distancing policy is still not comprehensive, this is because Social Distancing in it has dimensions of social and emotional relations. Students consider that direct social relations are very important. The influence of the lack of socialization from related parties about Social Distancing is also considered as not understanding the students about the Social Distancing policy. Literacy in social studies learning is an alternative for strengthening students' 
abilities to read, write, appreciate, and respond to all forms of events or events in their daily lives. There is a significant positive relationship between students' perceptions of social distancing policies and social studies literacy.

\section{REFERENCES}

[1] F. He, Y. Deng, and W. Li, "Coronavirus disease 2019: What we know?," J. Med. Virol., vol. 92, no. 7, pp. 719-725, 2020.

[2] D. Telaumbanua, "Urgensi Pembentukan Aturan Terkait Pencegahan Covid-19 Di Indonesia," QALAMUNA J. Pendidikan, Sos. dan Agama, vol. 12, no. 1, pp. 59-70, 2020.

[3] S. A. Tetep, "Students' digital media literacy: Effects on social character," Int. J. Recent Technol. Eng., vol. 8, no. 2, pp. 394-399, 2019.

[4] Tetep, "Optimalisasi Peran Iklim Sekolah bagi pembentukan karakter sosial Peserta didik," in International Seminar The Social Studies Contribution to Reach Periodic Environmental Education into Stunning Generation 2045, 2014, pp. 140-155, [Online]. Available: https://berita.upi.edu/see-expo/.

[5] T. Tetep, J. Jamilah, E. Dimyati, and O. Hermanto, "Opportunities or Challenges? Building Student Social Character through WhatsApp-Based Project Citizen in Disruptive Era," 2019.

[6] A. Romdhoni, Al Quran dan Literasi. Linus, 2013.

[7] P. Wiedarti, Desain induk gerakan literasi sekolah. Direktorat Jenderal Pendidikan Dasar dan Menengah, Kementerian Pendidikan, 2016.

[8] P. Retnaningdiyah, K. Laksono, N. Mujiyem, S. PS, and S. H. Umi, "Panduan Gerakan Literasi Sekolah di Sekolah Menengah Pertama," Jakarta Direktorat Pembin. Sekol. Menengah Pertama Direktorat Jenderal Pendidik. Dasar dan Menengah Kementeri. Pendidik. dan Kebud., 2016.

[9] P. Indonesia, "Undang-Undang Republik Indonesia nomor 6 Tahun 2018 tentang kekarantinaan kesehatan," Lembaran RI Tahun, no. 218, 2018.

[10] J. Jarolimek, Social studies competencies and skills: Learning to teach as an intern. Macmillan, 1977.

[11] UNESCO, The plurality of literacy and its implications for policies and programs: Position paper, vol. 13. Paris: UNESCO, 2004.

[12] Y. Abidin, T. Mulyati, and H. Yunansah, "Pembelajaran Literasi: Strategi Meningkatkan Kemampuan Literasi Matematika, Sains, Membaca, dan Menulis," Jakarta Bumi Aksara, 2017.

[13] USAID, Resource books for TTI lecturers Literacy in the primary school early grade for TTIs. New York: USAID, 2014.

[14] S. E. Pramono, Hakikat Pendidikan Ilmu
Pengetahuan Sosial. 2013.

[15] J. W. Creswell and J. D. Creswell, Research design: Qualitative, quantitative, and mixed methods approaches. Sage publications, 2017.

[16] C. Sälzer and J.-H. Heine, "Students' skipping behavior on truancy items and (school) subjects and its relation to test performance in PISA 2012," Int. J. Educ. Dev., vol. 46, pp. 103-113, 2016.

[17] A. E. Al Lily, A. F. Ismail, F. M. Abunasser, and R. H. A. Alqahtani, "Distance education as a response to pandemics: Coronavirus and Arab culture," Technol. Soc., vol. 63, p. 101317, 2020.

[18] R. Kern, Literacy and language teaching. Oxford University Press, 2000.

[19] E. S. Sari and S. Pujiono, "Budaya Literasi Di Kalangan Mahasiswa FBS UNY," LITERA, vol. 16, no. 1, 2017. 